\title{
Aerosol properties and meteorological conditions in the city of Buenos Aires, Argentina, during the resuspension of volcanic ash from the Puyehue-Cordón Caulle eruption
}

\author{
Ana Graciela Ulke ${ }^{1,2}$, Marcela M. Torres Brizuela ${ }^{1}$, Graciela B. Raga ${ }^{3}$, and Darrel Baumgardner ${ }^{4}$ \\ ${ }^{1}$ Departamento de Ciencias de la Atmósfera y los Océanos, Facultad de Ciencias Exactas y Naturales, Universidad de Buenos \\ Aires, Buenos Aires, Argentina \\ ${ }^{2}$ Unidad Mixta Internacional (UMI) - Instituto Franco Argentino sobre Estudios de Clima y sus Impactos (IFAECI), CNRS - \\ UMI-IFAECI-CNRS-3351, Buenos Aires, Argentina \\ ${ }^{3}$ Centro de Ciencias de la Atmósfera, Universidad Nacional Autónoma de México, Mexico City, CDMX, Mexico \\ ${ }^{4}$ Droplet Measurement Technologies, Boulder, CO, USA
}

Correspondence to: Ana Graciela Ulke (anagulke@gmail.com)

Received: 10 November 2015 - Published in Nat. Hazards Earth Syst. Sci. Discuss.: 15 January 2016

Revised: 22 June 2016 - Accepted: 7 September 2016 - Published: 27 September 2016

\begin{abstract}
The eruption in June 2011 of the Puyehue-Cordón Caulle Volcanic Complex in Chile impacted air traffic around the Southern Hemisphere for several months after the initial ash emissions. The ash deposited in vast areas of the Patagonian Steppe was subjected to the strong wind conditions prevalent during the austral winter and spring experiencing resuspension over various regions of Argentina.

In this study we analyze the meteorological conditions that led to the episode of volcanic ash resuspension which impacted the city of Buenos Aires and resulted in the closure of the two main airports in Buenos Aires area (Ezeiza and Aeroparque) on 16 October 2011. A relevant result is that resuspended material (volcanic ash plus dust) imprints a distinguishable feature within the atmospheric thermodynamic vertical profiles. The thermodynamic soundings show the signature of "pulses of drying" in layers associated with the presence of hygroscopic ash in the atmosphere that has already been reported in similar episodes after volcanic eruptions in other parts of the world. This particular footprint can be used to detect the probable existence of volcanic ash layers. This study also illustrates the utility of ceilometers to detect not only cloud base at airports but also volcanic ash plumes at the boundary layer and up to $7 \mathrm{~km}$ altitude.

Aerosol properties measured in the city during the resuspension episode indicate the presence of enhanced concentrations of aerosol particles in the boundary layer along with
\end{abstract}

spectral signatures in the measurements at the Buenos Aires AERONET site typical of ash plus dust advected towards the city. The mandatory aviation reports from the National Weather Service about airborne and deposited volcanic ash at the airport near the measurement site (Aeroparque) correlate in time with the enhanced concentrations. The presence of the resuspended material was detected by the CALIOP lidar overpassing the region. Since the dynamics of ash resuspension and recirculation are similar to the dynamics of dust storms, we use the HYSPLIT model with the dust storm module to simulate the episode that affected Buenos Aires. The results of the modeling agree qualitatively with satellite lidar measurements.

\section{Introduction}

At the end of April 2011, dozens of volcano-tectonic earthquakes mostly located at the Puyehue-Cordón Caulle Volcanic Complex (PCCVC: $40.59^{\circ} \mathrm{S}, 72.117^{\circ} \mathrm{W} ; 2236 \mathrm{~m}$ a.s.1.) in the Chilean Southern Andes were detected by the Observatorio Volcanológico de Los Andes del Sur dependent of Servicio Nacional de Geología y Minería (SERNAGEOMIN), which is the Chilean agency for geology and mining policies that monitors the volcanic activity and reports the level alerts. The seismic activity at the PCCVC continued with an 
increasing magnitude and the eruptive process finally began at 10:45 UTC (universal coordinated time) on 4 June 2011. During the initial phase of the subplinian eruption, a large plume of gases and ash particles was injected into the atmosphere up to $\sim 12-14 \mathrm{~km}$ height. The PCCVC volcanic activity declined until March 2012, when the red alert level was downgraded to orange and was subsequently switched to yellow on 24 April 2012. This status alert remained until August 2012, when the alert level was finally set to green. A detailed chronological description of the volcanic eruption and a modeling of the volcanic ash dispersion during the main phase explosive events are reported by Collini et al. (2013). A field-based reconstruction of the volcanic eruption eruptive phases with a detailed characterization of the stratigraphy and deposit features during the entire eruption sequence is presented by Pistolesi et al. (2015) and the exact details of tephra sedimentation and grain size are presented by Bonadonna et al. (2015a). The determination of physical parameters during the main eruptive phase in relationship with the eruption classification and the characterization of the plume dynamics and spreading is also conducted by Bonadonna et al. (2015b).

As a result of this eruption many airports were closed and flights were canceled in Chile, Uruguay and Argentina because of the potentially hazardous operating conditions. The PCCVC eruption also impacted air traffic throughout the Southern Hemisphere for several days from South America to Oceania, as prevailing winds at higher levels (300$600 \mathrm{hPa}$ ) over this region were strong and westerly.

The eruption of the PCCVC occurred during an extended field campaign when measurements of the properties of atmospheric aerosol particles were being made in the city of Buenos Aires (CABA) to characterize air pollution (Ulke et al., 2011; Raga et al., 2013). As reported by Raga et al. (2013), four case studies coincident with the arrival of the ash plume over the Buenos Aires area that led to airport closures were analyzed and evaluated. From these cases the vertical profiles of aerosol backscatter, measured with a ceilometer, clearly identified the presence of the volcanic ash.

It is well documented that volcanic ash can be hazardous to flight operations because ash particles have silicate compounds that can reach their melting point in the jet engine turbines and subsequently crystallize on the turbine blades. This leads to costly and sometimes deadly damage (Casadevall, 1993, 1994). However, fresh volcanic ash emissions are not the only factors that can be hazardous. The ash deposited at the surface from previous eruptions can be resuspended by winds and advected to other regions, as has been reported in various studies. In particular, Hadley and Hufford (2004) reported an episode of resuspended ash in Alaska during September 2003 and observed that the plume of lofted ash reached an altitude of over $1600 \mathrm{~m}$ and extended $230 \mathrm{~km}$ over the Gulf of Alaska. Leadbetter et al. (2012) modeled resuspended ash in case studies after the Eyjafjallajökull eruption using NAME (Numerical Atmospheric-dispersion Modeling
Environment), the UK Met Office's Lagrangian particle dispersion model (Jones et al., 2007), and found good agreement with $\mathrm{PM}_{10}$ observations and satellite RGB dust product images. The dynamics of the resuspension of volcanic ash is quite similar to dust storm episodes and the resuspension of volcanic ash has been widely studied and modeled as dust storms (e.g., Gillette and Passi, 1988; Gu et al., 2003; Freudenthaler, 2006; Jugder et al., 2011; Dupart et al., 2012).

An episode of resuspension associated with the PCCVC activity occurred in Argentina from 14 to 17 October 2011, which impacted air traffic around Buenos Aires on 16 October where all flight operations were canceled by the national authorities (Secretary of Transport). The international airport in Montevideo, Uruguay, was closed to flight operations on 17 October with reports of ash deposited on the runways. Measurements were still being made in the aforementioned field campaign during this period and provide a unique opportunity to assess the impact of the resuspended ash and to evaluate models used to predict resuspension events. Folch et al. (2014) performed numerical simulations of the episode reported in this paper with the FALL3D model, focusing on the calibration of a variety of model parameters and treatments, including the resuspension process of ash deposited at the surface.

The objectives of this paper are

- to analyze the near-surface and tropospheric thermodynamic and kinematic conditions that led to the resuspension of deposited volcanic ash into the atmospheric boundary layer and its transport towards the Buenos Aires area

- to assess changes in the atmospheric moisture content and temperature of the thermodynamic vertical profiles due to the presence of the ash plume

- to evaluate changes in the aerosol properties and concentrations in Buenos Aires during the resuspension event

- to evaluate the performance of the Hybrid SingleParticle Lagrangian Integrated Trajectory (HYSPLIT) (Draxler and Hess, 1998) model as a tool to predict ash resuspension.

\section{Measurements and methodology}

\subsection{Geographical location}

The ash from the eruptions of the PCCVC (Fig. 1a) in 2011 were deposited predominantly downwind in Argentina, in an arid region known as the Patagonian Steppe. The bare soil in this arid region, combined with the prevailing and strong westerly winds, promotes the occurrence of dust storms. The Patagonian Steppe is an extended (around $650000 \mathrm{~km}^{2}$ ) and semiarid region with scarce native vegetation. The northern 

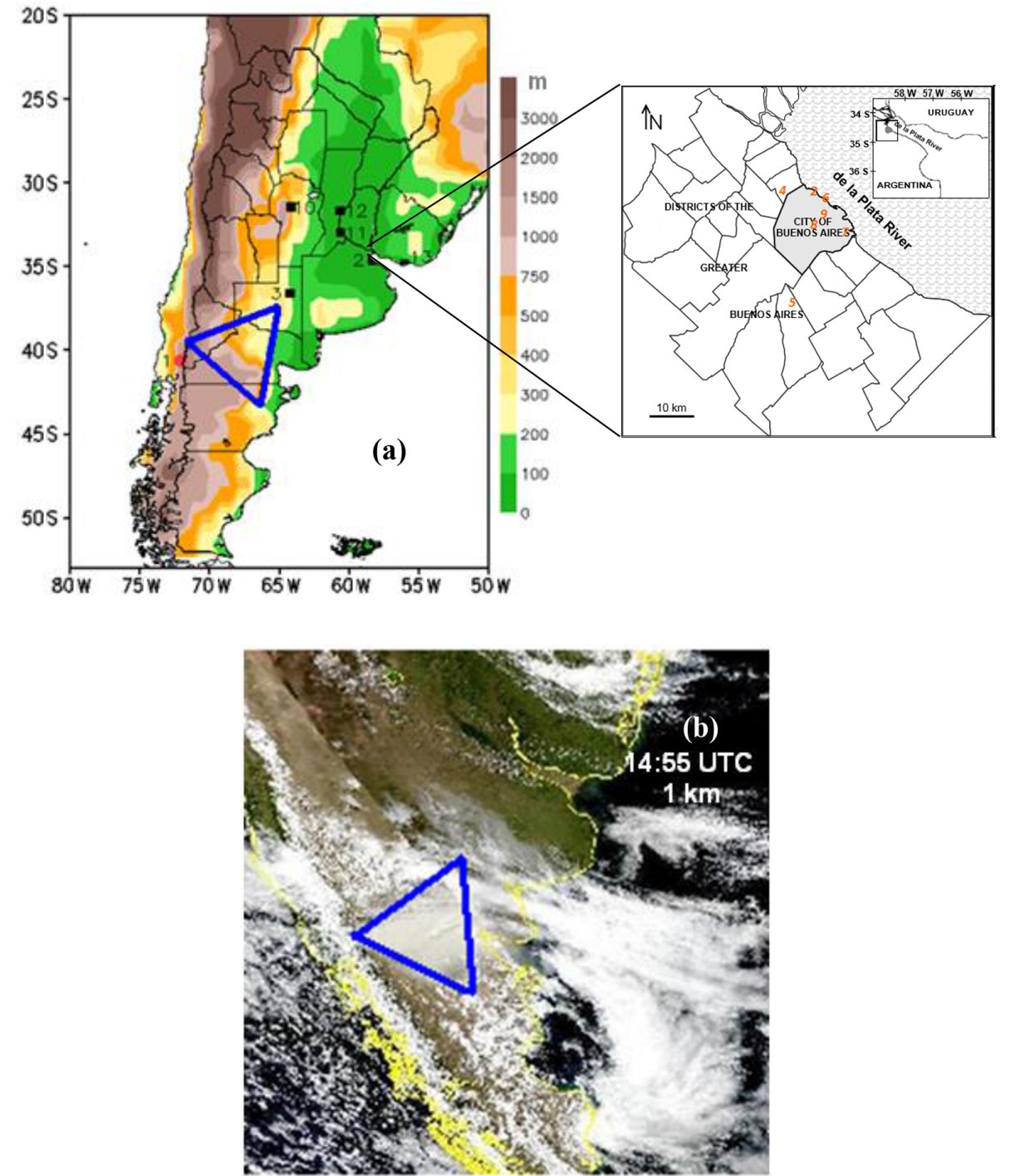

Figure 1. (a) Topography of Argentina and location of sites. The color bar indicates the height ranges (in meters). The right panel zoom is the Buenos Aires Metropolitan Area. The marks indicate the locations of (1) PCCVC, Chile; (2) CU-CABA; (3) Santa Rosa, La Pampa; (4) CEILAP-BA, Buenos Aires; (5) Ezeiza, Buenos Aires; (6) Aeroparque, CABA; (7) La Boca, CABA; (8) Centenario, CABA; (9) Córdoba, CABA; (10) Córdoba, Córdoba; (11) Rosario, Santa Fé; (12) Santa Fé, Santa Fé; (13) Carrasco, Montevideo. (b) MODIS Aqua image on 15 October 2011 at 14:55 UTC (1 km resolution). The blue triangle denotes the ash/dust removal area.

border is an approximate diagonal that goes from $36.5^{\circ} \mathrm{S}$, $70.5^{\circ} \mathrm{W}$ to $39.5^{\circ} \mathrm{S}, 62^{\circ} \mathrm{W}$. The western and southern limits are variable and located close to the Andes Mountains and around $52^{\circ} \mathrm{S}$ respectively. The temporal variability of the area is mainly due to the precipitation and temperature regimes - in particular, the winter accumulated precipitation (Fabricante et al., 2009). It is worth mentioning that the climatological analysis provided by the National Weather Service (SMN Spanish acronym of Servicio Meteorologico Nacional) on its climatological reports (accessed at http://www.smn.gov.ar/serviciosclimaticos/ on December 2011) indicated a dry period during 2011.
The resuspended volcanic ash is seen in the Moderate Resolution Imaging Spectroradiometer (MODIS) $1 \mathrm{~km}$ resolution visible data on 15 October at 14:55 UTC in Patagonia (Fig. 1b). The results presented by Pujol et al. (2013) helped to confirm the volcanic origin of the detected aerosol layer. To identify the source of the ash/dust plume they used the concept based on reverse absorption (Prata, 1989) and 3.9/11/12 $\mu \mathrm{m}$ band empirical algorithm (Ellrod et al., 2003). A technical report from the Instituto Nacional de Tecnología Agropecuaria (Gaitán et al., 2011) based on field measurements depicts the deposition zone (isopachs) in the same area. The report analyzes the spatial distribution of the ash over the Patagonian Steppe 6 months after the initial erup- 
tion, the relationship between the particle sizes, the soil and vegetation types. They also considered in their analysis the precipitation regimes and the soil moisture content. These data are relevant in the resuspension or remobilization of the deposited ash.

\subsection{Datasets}

The instrumentation deployed at Ciudad Universitaria (CU) $\left(34.58^{\circ} \mathrm{S}, 58.37^{\circ} \mathrm{W}\right.$; at $30 \mathrm{~m}$ a.s.l.) during the field campaign to evaluate urban aerosol pollution is described by Ulke et al. (2011) and Raga et al. (2013), including a discussion of the associated measurement uncertainties and limitations. However, for the purpose of this study, we will only concentrate on the data obtained with the Vaisala CL31 ceilometer, a remote sensing instrument located at the site that provides the vertical profile of backscattered light from aerosols at a wavelength of $910 \mathrm{~nm}$. The vertical resolution of the ceilometer is $20 \mathrm{~m}$, ranging up to an altitude of $7000 \mathrm{~m}$. The measurement frequency of the instrument is $0.5 \mathrm{~Hz}$, but the data were averaged over $10 \mathrm{~min}$ intervals. The ceilometer backscatter measurements were converted to extinction coefficients using a least squares analysis with the in situ measurements of scattering and absorption, as described in detail in Raga et al. (2013).

Additional information on aerosol optical properties was obtained from the AERosol RObotic NETwork (AERONET) site CEILAP-BA $\left(34.57^{\circ} \mathrm{S}, 58.5^{\circ} \mathrm{W} ; 10 \mathrm{~m}\right.$ a.s.l.), which is maintained and operated by personnel at Centro de Investigaciones en Láseres y Aplicaciones and is located approximately $4 \mathrm{~km}$ west of the CU site. AERONET is a global network of surface-based stations that provide continuous information for the study of aerosol properties. This site was established by the National Aeronautics and Space Administration (NASA) and PHOTONS (PHOtométrie pour le Traitement Opérationnel de Normalisation Satellitaire; Univ. of Lille 1, CNES, and CNRS-INSU) and currently there are numerous collaborators worldwide. The data are freely available at $\mathrm{http}: / /$ aeronet.gsfc.nasa.gov/. The detailed information on detection limits, limitations and assumptions for the retrieval, inversion algorithms and quality-control procedures is discussed in detail by Holben et al. (1998), Eck et al. (1999), Smirnov et al. (2000), Dubovik et al. (2002) and O'Neill et al. (2001a, b, 2003). Additional information is available on the AERONET web page (http://aeronet. gsfc.nasa.gov/new_web/system_descriptions.html and http: //aeronet.gsfc.nasa.gov/new_web/publications.html).

The observations are made with sun photometers of type CIMEL at multiple wavelengths $(340,380,440,500,670$, 870,1020 and $1640 \mathrm{~nm}$ ) (Holben et al., 1998). The measurements are provided for three quality levels (level 1: unscreened; level 1.5: cloud screened; level 2: cloud screened and quality assured after a seven-step procedure) and their uncertainty ranges from 0.01 to 0.02 (Eck et al., 1999; Smirnov et al., 2000). Data intermittence is mainly due to cloudiness over the site and/or the detection of anomalous values on the basis of their temporal variance.

The aerosol optical depth (AOD) is a measure of the extinction of solar radiation by the presence of aerosols in an atmospheric layer through which the light is traveling and indicates the columnar aerosol load in the local atmosphere. Several quantities are obtained from the measurements using inversion algorithms based on the AOD spectral dependence (e.g., aerosol size distributions, single scattering albedo, refractive indices and asymmetry parameter).

The Ångström exponent $(\alpha)$ shows the variation of the AOD with the wavelength $(\lambda)$ of incident light. The 440$870 \mathrm{~nm}$ Ångström exponent $\left(\alpha_{440-870}\right)$ is computed from linear regression of $\ln$ AOD vs. $\ln \lambda$ for all AOD data available between the wavelengths of 440 and $870 \mathrm{~nm}$ and provides important information on the particle size distribution (Dubovik et al., 2002). The larger Ångström exponents are due to higher spectral variation in AOD and are associated with smaller particles. Contrarily, the lower values of $\alpha$ indicate dominance of coarse-mode aerosol. Aerosol particles in the fine fraction are typical from urban/anthropogenic pollution (combustion products from fossil fuel or biomass burning) whereas those associated with natural sources belong to the coarse fraction (dust, marine aerosol, volcanic ash, bioaerosol) (Seinfeld and Pandis, 2006).

The AERONET fine-mode fraction $\mathrm{AOD}_{500 \mathrm{~nm}}$ product (FMF) is the ratio of fine to total AOD obtained with the spectral deconvolution algorithm (SDA) using the measurements from 380 to $870 \mathrm{~nm}$. The detailed information and evaluation of the SDA along with the assumptions and errors is fully documented in O'Neill et al. (2001a, b, 2003, 2006). Specifically, the FMF is an estimation of the optical effects of the fine-mode particles based on the spectral curvature in the observed optical depths instead of a cutoff radius. It is more robust because it can be applied in the cases of mixed aerosols (e.g., desert dust and combustion aerosols, clouds and smoke).

The quantities that were selected for analysis were the $\mathrm{AOD}_{500 \mathrm{~nm}}$, the FMF $\mathrm{AOD}_{500 \mathrm{~nm}}$ and the Ångström exponent $\left(\alpha_{440-870)}\right)$ level 2 data.

Products obtained from the observations of the CloudAerosol Lidar and Infrared Pathfinder Satellite Observations (CALIPSO) are also analyzed. The products are distributed by the NASA Atmospheric Science Data Center and are freely available at http://www-calipso.larc.nasa.gov/. Details of the products can be found in the CALIPSO Data Products Catalog (Powell et al., 2013). The Cloud-Aerosol Lidar with Orthogonal Polarization (CALIOP) is the primary instrument on the CALIPSO satellite. CALIOP acquires vertical profiles of elastic backscatter at two wavelengths (1064 and $532 \mathrm{~nm}$ ) from a near-nadir-viewing geometry during both day and night phases of the orbit. In addition to the total backscatter at the two wavelengths, CALIOP also provides profiles of linear depolarization at $532 \mathrm{~nm}$. The detection limit is determined by a threshold setting in the layer detection algo- 
rithm (Vaughan et al., 2009). At night this threshold is about $2 \times 10^{-4} \mathrm{~km}^{-1} \mathrm{sr}^{-1}$ in the mid- to lower troposphere and during daytime is a factor of 2 to 5 less sensitive.

The profiles are used by a scene classification algorithm composed of three submodules: cloud-aerosol discrimination (CAD) (Liu et al., 2009), aerosol subtyping (Omar et al., 2009) and cloud ice-water phase discrimination (Hu et al., 2009). Only two classes of tropospheric features are defined in the CAD algorithm: "cloud" and "aerosol". The first class includes clouds, fogs and mists, whereas hazes belong to the aerosol class. The aerosol classification algorithm only operates on those inputs from the CAD algorithm that have been classified as aerosols. Six aerosol types are defined: clean continental, clean marine, dust, polluted continental, polluted dust and smoke. To determine aerosol type, these algorithms use the volume depolarization ratio (the ratio of the perpendicular to parallel components of the total attenuated backscatter) and the integrated attenuated backscatter (the vertical integral of the product of the backscatter and atmospheric transmittance due to particles and molecules between the base and the top of the detected layer), along with information on surface type and layer altitude. The volume depolarization ratio is used to identify aerosol types with a substantial mass fraction of aspherical particles (e.g., a mixture of smoke and dust). The integrated attenuated backscatter is used to discern instances of transient high aerosol loading over surfaces where this is not usually expected. The total attenuated color ratio (the ratio of the total attenuated 1064 and $532 \mathrm{~nm}$ backscatters) is not used in the subtyping algorithm and is an independent quantity that contributes to classify the features.

Although the standard processing algorithms do not attempt to identify material as volcanic, CALIOP observations have been used to study the plumes from a number of volcanic eruptions. Polarized lidar backscatter signals can be used to discriminate between ash and sulfate aerosol resulting from volcanic emissions because light scattered from spherical particles, such as sulfate aerosol droplets, retain the linear polarization of the incident light, whereas backscatter from irregular solid particles, like ash, is depolarized (Winker et al., 2012; Vernier et al., 2013).

According to Winker et al. (2012), about half the ash layers from Eyjafjallajökull were classified as cloud, and otherwise as either "desert dust" or "polluted dust", due to the depolarization signature of the ash. They identified the layers of volcanic origin by visual inspection of backscatter, volume depolarization and attenuated color ratio browse images and also considered the altitude and layer morphology to help distinguish the plumes from cirrus, desert dust and boundary layer aerosols. Based on similarities found by Schumann et al. (2011) between the measured properties (size distribution, composition and shape) of transported Eyjafjallajökull ash and desert dust, Winker et al. (2012) assumed that ash plumes observed after transport of more than 1 day will have optical properties similar to those of transported desert dust.
Aiming to improve volcanic ash warnings for aviation safety, Vernier et al. (2013) developed a methodology to discern low volcanic ash loadings and to describe the three-dimensional structure of the ash cloud. The method is based on visual inspection of optical properties (depolarization and color ratios) of the ash plume from the PCCVC detected by CALIOP at altitudes near 6-13 km over Australia and New Zealand. In this contribution we use a similar approach to Winker et al. (2012) and Vernier et al. (2013): the inspection of the CALIPSO browse images of total integrated backscatter, volume depolarization ratio and color ratio and the comparison of the retrieved values in our case with those reported in their papers.

The surface data from synoptic stations located at the Buenos Aires airports (Ezeiza and Aeroparque), the mandatory aviation weather reports (scheduled/not scheduled) METAR (METeorological Airport Report)/SPECI (SPECIal meteorological airport report) and upper-air observations at 12:00 UTC (09:00 LST) were provided by the SMN. An extended analysis was performed on the radiosondes launched from the airports in Ezeiza ( $34.82^{\circ} \mathrm{S}, 58.53^{\circ} \mathrm{W} ; 20 \mathrm{~m}$ a.s.1.) and Santa Rosa $\left(36.57^{\circ} \mathrm{S}, 64.27^{\circ} \mathrm{W} ; 190 \mathrm{~m}\right.$ a.s.l.). Santa Rosa represents the northern limit of the Patagonian Steppe and Ezeiza is the closest to the experimental site (see Fig. 1a). Regarding the surface meteorological information, the wind speed and direction at Aeroparque and the METAR/SPECI reports were considered in order to relate the dispersion conditions with the aerosol measurements.

The Global Data Assimilation System (GDAS) at $1^{\circ} \times 1^{\circ}$ resolution of the National Center for Environmental Prediction (NCEP) meteorological data were used to analyze the meteorological conditions and to drive the HYSPLIT model.

Finally, the official data from the air quality network of the government of the city of Buenos Aires (GCBA) were analyzed to independently confirm the impact of the resuspended ash. The government of the city of Buenos Aires operates three air quality monitoring stations (Centenario: $34.61^{\circ} \mathrm{S}, 58.43^{\circ} \mathrm{W}, 27 \mathrm{~m}$ a.s.1.; Córdoba: $34.60^{\circ} \mathrm{S}, 58.39^{\circ} \mathrm{W}$, $35 \mathrm{~m}$ a.s.1.; La Boca: $34.62^{\circ} \mathrm{S}, 58.36^{\circ} \mathrm{W}, 11 \mathrm{~m}$ a.s.l.) that measure and report concentrations of aerosol particles with aerodynamic diameters smaller than $10 \mu \mathrm{m}\left(\mathrm{PM}_{10}\right)$ according to methodologies and calibration procedures established by the US EPA (Environmental Protection Agency) regulations. The instrument is the Thermo Scientific Beta Gauge Continuous Ambient Particulate Monitor (FH62C14) that measures continuously the attenuation of the $\mathrm{C} 14$ beta rays according to International Particulate Monitoring regulations. The data from the La Boca station (located $\sim 13 \mathrm{~km}$ from $\mathrm{CU}$ ) were selected since the station is close to the river and has similar geographic characteristics as the $\mathrm{CU}$ site. La Boca started to operate on May 2009 and PM $_{10}$ measurements are available from 2010. Daily means and monthly reports according to the GCBA and EPA regulations are freely available at http://www.buenosaires.gob.ar/ agenciaambiental/monitoreoambiental. PM $_{10}$ hourly concen- 
trations for the analyzed period were provided upon request by the air quality division of the city government (GCBA, 2016). The measured values and their evolution during this event were analyzed and compared to the typical urban values.

\section{Analysis of the meteorological conditions}

\subsection{Vertical profiles}

The thermodynamic evolution during this case study is illustrated by the vertical profiles shown in Fig. 2. The Santa Rosa and Ezeiza soundings are analyzed for 14 to 16 and from 15 to 17 October, respectively, following the northeastward displacement of the volcanic plume. These are compared with the mean decadal soundings obtained by Velasco and Necco (1980).

The Santa Rosa thermodynamic profiles exhibit a warm layer located from the surface to $\sim 800 \mathrm{~m}$ throughout the period analyzed compared to the mean temperature profile (Fig. 2a). Note that initially the near-surface temperature inversion is shallow (compared to the mean) and weakens with time, evolving into an adiabatic lapse rate. This evolution is mainly driven by the stronger radiative heating of the surface (almost bare soil covered with volcanic ash), not by advection or turbulent mechanical mixing. As the difference between the temperature $(T)$ and the dew point temperature $\left(T_{\mathrm{d}}\right)$ at fixed levels is proportional to the relative humidity, dry layers are observed that are likely associated with the presence of a mixture of silica and dust in the air (Lathem et al., 2011). On 14 October 2011 the dry layer extended from 300 to $1200 \mathrm{~m}$. Note that in this layer the mixing ratio (the water vapor content, $\mathrm{g}$, per unit of dry air, $\mathrm{kg}$ ) decreased from 5.2 to $0.8 \mathrm{~g} \mathrm{~kg}^{-1}$. Although this behavior continued on the following day, the drying diminished (mixing ratio varied between 5.2 and $2.7 \mathrm{~g} \mathrm{~kg}^{-1}$ ). Schumann et al. (2011) and Miffre et al. (2012) also reported this atmospheric behavior in their analysis of the Eyjafjallajökull eruption. The relevant dynamic features of the vertical profiles are as follows:

i. between 14 and 15 October the wind speed is accelerating above $300 \mathrm{~m}$, hence increasing in the potential to resuspend and transport the ash;

ii. veering of the wind from west to mainly south throughout the free troposphere on 15 and 16 October produces the ash displacement towards the northeast (Fig. 2a).

The Ezeiza thermodynamic profiles also exhibit warmer conditions than the climatological mean values (Fig. 2b) up to $\sim 1.5 \mathrm{~km}$ height during the first $48 \mathrm{~h}$; however, on 17 October 2011 the temperature is lower, coinciding with the northeastward movement of the high-pressure system that covers northern Patagonia and central Argentina (Fig. 3). A drier atmosphere than the mean decadal values (Fig. 2b) is also evident. This feature is prominent on 16 October, which shows a
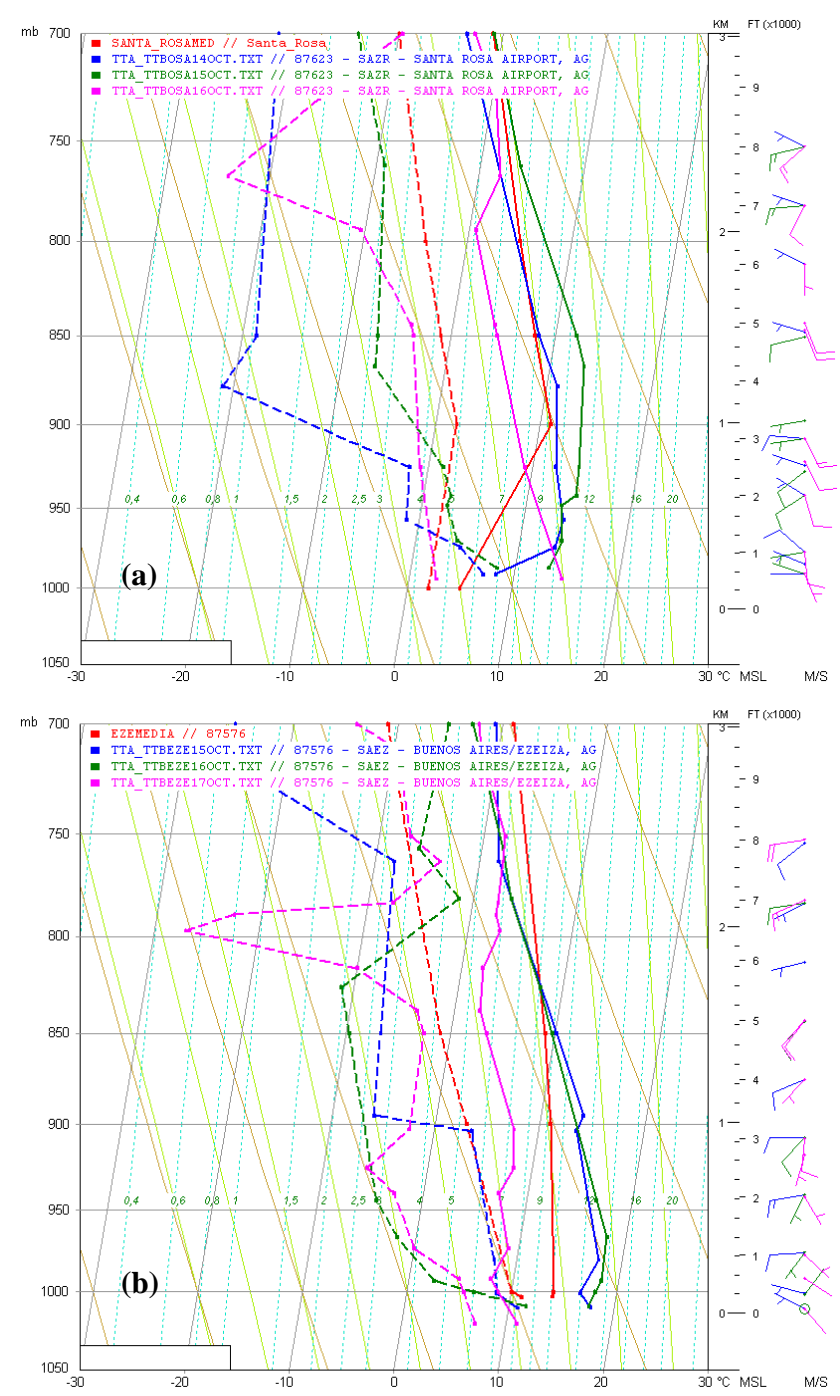

Figure 2. Thermodynamic profiles at 12:00 UTC over (a) Santa Rosa and (b) Ezeiza: wind (in $\mathrm{ms}^{-1}$, barbs) and temperatures (in ${ }^{\circ} \mathrm{C}$; air temperature is the solid line and dew point temperature is the dotted line). The red curves are the mean decadal soundings obtained by Velasco and Necco (1980).

dry layer from the surface up to $1.8 \mathrm{~km}$ and an extreme drying in the layer from the surface up to $400 \mathrm{~m}$. The mixing ratio decreased from 8.5 to $3.5 \mathrm{~g} \mathrm{~kg}^{-1}$ (Fig. 2b). This drying is also associated with static stability coinciding with the presence of the resuspended material over Buenos Aires. The wind speed at the surface decreased from $5 \mathrm{~ms}^{-1}$ to mostly calm during this period (Fig. 2b), contributing to stagnation and increased ambient aerosol concentration (see Fig. 5a, b, c).

\subsection{Synoptic analysis}

The analysis of the relevant synoptic-scale features every $6 \mathrm{~h}$ was performed for several days prior to the resuspension 

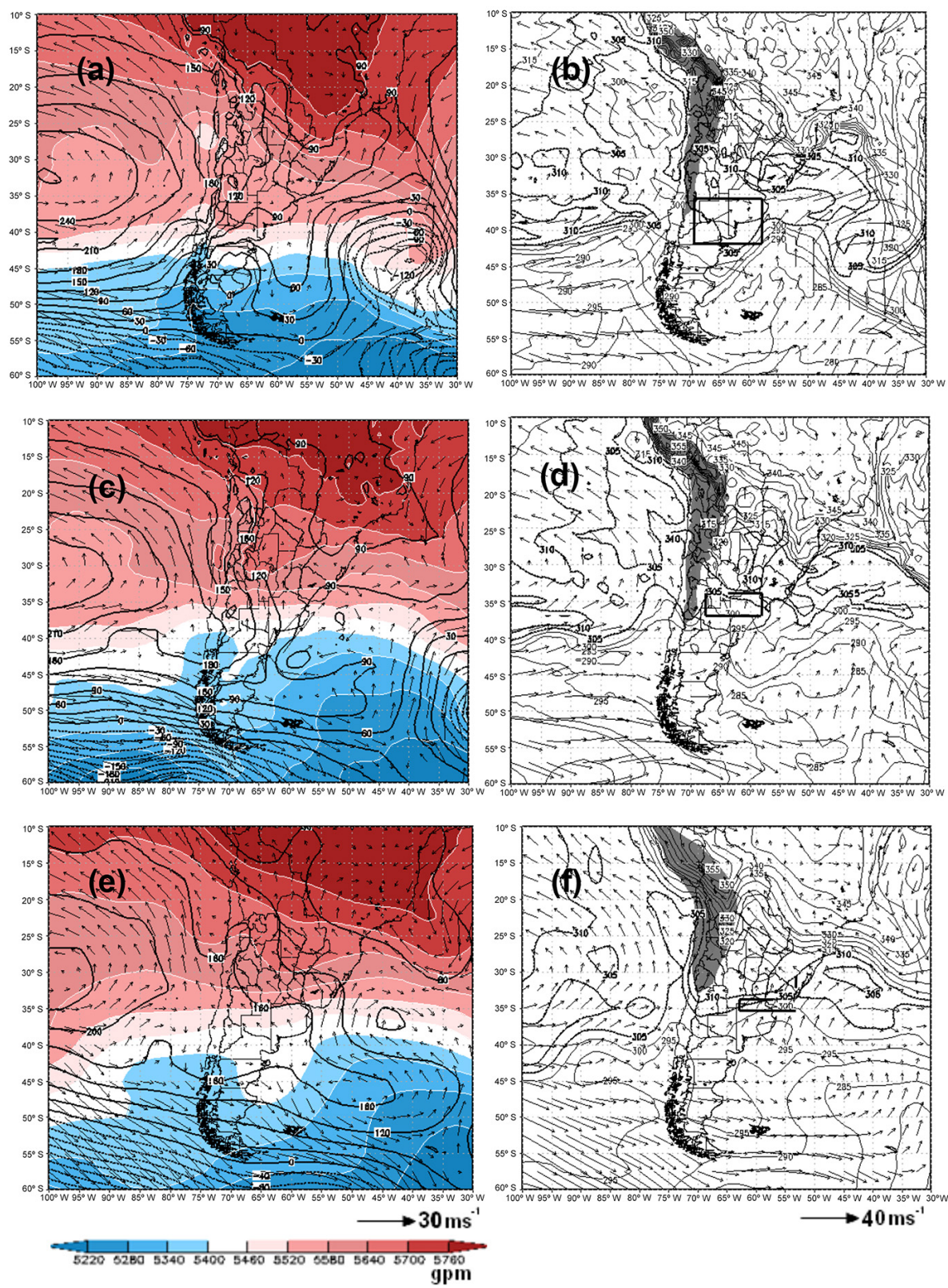

Figure 3. (a, c, e) Geopotential heights at $1000 \mathrm{hPa}$ (in gpm, black contours) and 500-1000 thickness fields (in gpm, shaded); $1000 \mathrm{hPa}$ horizontal wind (in $\mathrm{ms}^{-1}$, vectors) at 12:00 UTC on (a) 15 October, (c) 16 October and (e) 17 October. (b, d, f) Equivalent adiabatic potential temperature $\left(\theta_{\mathrm{e}}\right)$ (in $\mathrm{K}$, dotted contours) and horizontal wind (in $\mathrm{ms}^{-1}$, vectors) at $850 \mathrm{hPa}$ at 12:00 UTC on (b) 15 October, (d) 16 October and (f) 17 October. The black box indicates the $\theta_{\mathrm{e}}$ values $\sim 305 \mathrm{~K}$.

event, but only the times that coincide with the radiosonde launches at Ezeiza shown in Fig. $2 \mathrm{~b}$ are presented here.

On 15 October at 12:00 UTC an anticyclonic system was centered at about $32^{\circ} \mathrm{S}, 95^{\circ} \mathrm{W}$, accompanied by a lowpressure system in southern Patagonia (Fig. 3). The associated horizontal pressure gradient produces strong nearsurface southwesterly winds as far north as $\sim 40^{\circ} \mathrm{S}$, capable of lifting the deposited ash. The contours of the 500-1000 thickness reveal a relatively warm air mass in northern Patag- onia (Fig. 3a). North of $40^{\circ} \mathrm{S}$ near-surface winds were weak, in accordance with the upper-air measurements. The equivalent potential temperature $\left(\theta_{\mathrm{e}}\right)$ at $850 \mathrm{hPa}$ is used to follow the suspended ash and the value of $\sim 305 \mathrm{~K}$ is considered indicative of the air mass which is restricted to an undulating region located between 42 and $35^{\circ} \mathrm{S}$ (Fig. 3b). The location of this air mass coincides with an area of anticyclonic vorticity at $500 \mathrm{hPa}$ (not shown) indicating a stable synoptic environment. 


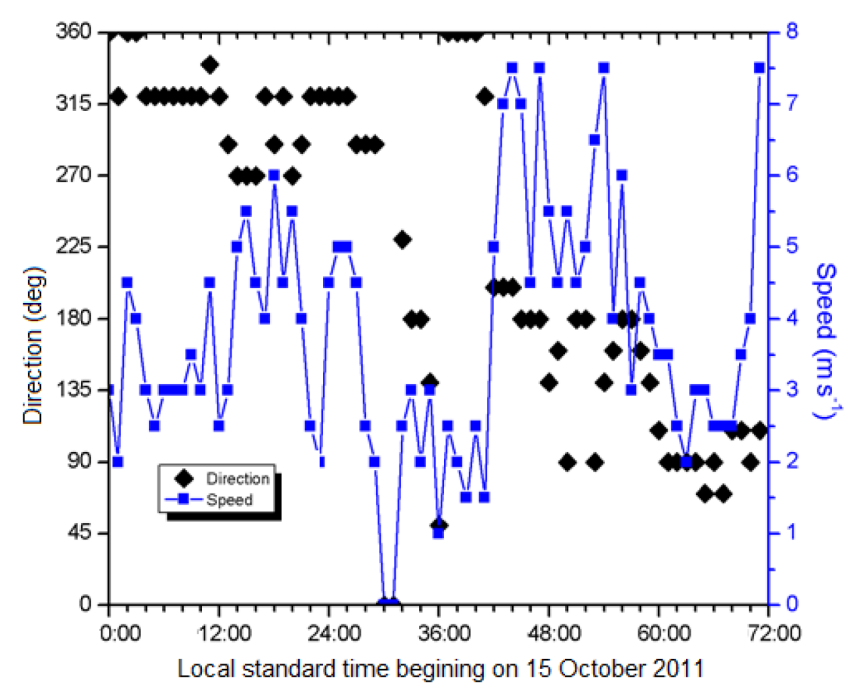

Figure 4. Surface wind speed (blue line, in $\mathrm{ms}^{-1}$ ) and direction (black marker, in degrees) at Aeroparque.

On 16 October at 12:00 UTC the contour of $\theta_{\mathrm{e}} \approx 305 \mathrm{~K}$ is observed over the northern area of Buenos Aires (Fig. 3d) coincident with the warm layer represented by the 500-1000 thickness (Fig. 3c). Buenos Aires is located between a lowpressure system over the Atlantic Ocean and an anticyclonic system to the west (Fig. 3d). The associated airflow shows a strengthening of near-surface winds that advect the ash towards the region of Buenos Aires. During the first $12 \mathrm{~h}$ of 17 October, the high-pressure system extended to the Atlantic Ocean $\left(\approx 40^{\circ} \mathrm{W}\right)$ and, in the area of the city, the nearsurface winds became easterly as shown in Fig. 3e. The $\theta_{\mathrm{e}}$ values of $305 \mathrm{~K}$ are displaced to the north of Buenos Aires (Fig. 3f), and the city of Buenos Aires was no longer under the influence of the volcanic ash.

Surface winds at Aeroparque (Fig. 4) on 15 October are from the NW sector, ranging from 2 to $6 \mathrm{~ms}^{-1}$, with the maximum strength at 15:00 LST. Calm conditions in the early morning hours of 16 October are followed by light winds $\left(2 \mathrm{~ms}^{-1}\right)$ with variable directions. An anticlockwise veering is observed from SW to N till 15:00 LST. A large wind increase occurred after that time (reaching $\sim 7.5 \mathrm{~ms}^{-1}$ ), along with a clockwise turning consistent with the entrance of the high-pressure system previously mentioned. The increase of the surface wind promotes turbulent mixing and the resulting enhancement of the mixing layer height (see Fig. 5a). The following day wind comes from the SE sector with the highest intensities $\left(\sim 7 \mathrm{~ms}^{-1}\right)$ at the beginning of the day and the least $\left(\sim 2 \mathrm{~ms}^{-1}\right)$ around midday, in agreement with the highest extinction magnitudes registered by the ceilometer (see Fig. 5a).

The presence of volcanic ash was reported on 16 and 17 October by the METAR/SPECI reports. The Aeroparque airport reported the presence of ash from 08:00 UTC on 16 October until 08:00 UTC on 17 October. Ezeiza and Car- rasco (Uruguay) airports documented it from 13:00 UTC on 16 October until 09:00 UTC 17 October and from 13:00 UTC on 16 October to 17:00 UTC on 17 October respectively. All airports in the area were closed for flight operations during the whole day due to the presence of volcanic ash not only in the atmosphere but also deposited on the runways.

\section{Analysis of aerosol properties}

\subsection{Surface-based measurements}

The objective of the $24 \mathrm{~h}$ continuous measurements obtained with the instrumentation deployed at the research site in CU was to evaluate the properties of ambient aerosols associated with urban emissions. Nevertheless, those measurements can also help to identify the presence of non-urban aerosol during the episodes of volcanic ash.

In accordance with the meteorological reports, the ceilometer measurements (Fig. 5a) indicate the arrival of the resuspended ash around midnight on 15 October and the persistence during 16 October. On 15 October the small values of the extinction coefficient from the ceilometer are indicative of a clean air mass over the measurement site. In contrast, large extinction values denote the presence of the volcanic ash the early hours of 16 October and persisting for many hours. During nighttime and early morning hours, aerosols were present in a layer that extended up to $\sim 500 \mathrm{~m}$. Recall from the results in the previous section that the wind was calm in Buenos Aires during this day, leading to higher ambient concentrations of particles with a large extinction signal. The development of the convective boundary layer is evident from the ceilometer data after local noon, with aerosols reaching a mean height of $1000 \mathrm{~m}$ late in the afternoon and the top of the plume of aerosols at $2000 \mathrm{~m}$. On the day of the arrival of the resuspended ash, the plume appears highly nonuniform with different "filament-like" layers contributing to enhance the near-surface concentrations throughout most of the day.

A remarkable feature is that the layer with the highest extinction values $\left(\sim 100 \mathrm{Mm}^{-1}\right)$ in the ceilometer measurements shown in Fig. 5a is coincident with the important drying observed in the Ezeiza thermodynamic sounding (see Sect. 3.1). The highly variable extinction coefficient throughout 16 October reflects the inhomogeneity of the aerosol layer and the effect of mechanical and thermal turbulence. By 17 October the larger-scale circulations have moved the ash away from the Buenos Aires region as is evident in the temporal evolution of the extinction coefficient, which is consistent with the typical urban plume, initially in a shallow, stable boundary layer followed by a well-developed convective boundary layer (see Fig. 5a).

The influence of the resuspended ash is also seen in the $\mathrm{PM}_{10}$ measurements. All the monitoring network sites in the city show increased concentrations of $\mathrm{PM}_{10}$ and the $\mathrm{La}$ 

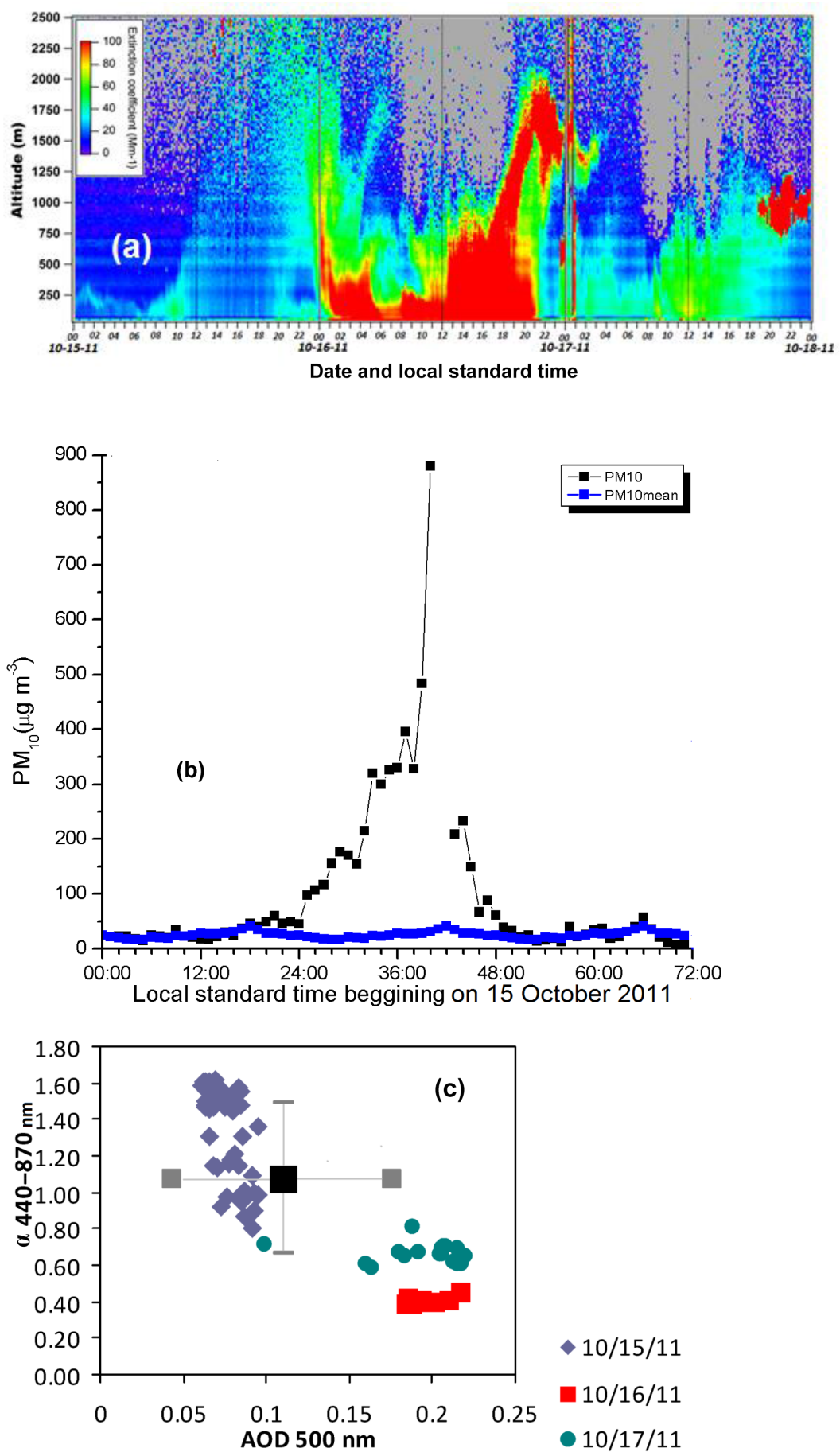

Figure 5. Time evolution (LST) for the 3-day period from 15 to 17 October of (a) the extinction coefficient (in $\mathrm{Mm}^{-1}$ ) derived from ceilometer and (b) the hourly $\mathrm{PM}_{10}$ concentration (black marker and line, in $\mu \mathrm{gm}^{-3}$ ). The blue line indicates the typical urban mean values. (c) Variation of the Ångström exponent $(\alpha 400-870 \mathrm{~nm})$ with the $\mathrm{AOD}_{500 \mathrm{~nm}}$. The black square indicates the relation amongst the October long-term means (1999 to 2012 excluding 2011). The gray bars indicate the AOD $500 \mathrm{~nm}$ and $\alpha 440-870$ nm standard deviations. 
Boca station shows values much larger than the GCBA and EPA standard of $150 \mu \mathrm{gm}^{-3}$. The typical daily values (based on data from 2010 to 2015 excluding 2011) during October are $25 \mathrm{\mu gm}^{-3}$ for the mean with a standard deviation of $\pm 9 \mathrm{\mu gm}^{-3}$.

Note that the $\mathrm{PM}_{10}$ concentration at La Boca (Fig. 5b) starts to increase around midnight on 15 October, consistent with the resuspended ash plume arriving into the city. The average hourly value of $\mathrm{PM}_{10}$ at this station for all other days during the month of October is only about $25 \mu \mathrm{gm}^{-3}$. The hourly $\mathrm{PM}_{10}$ concentrations show an important and rapid build-up on 16 October, from around $100 \mu \mathrm{gm}^{-3}$ at 01:00 LST, reaching the maximum $\left(\sim 900 \mu \mathrm{gm}^{-3}\right)$ in the afternoon and persisting until midnight. By 17 October the ash plume has either been advected out of the region or mostly deposited onto the surface, since $\mathrm{PM}_{10}$ concentrations decreased to approach the typical background values. This behavior is consistent with the ceilometer measurements and those reported by Folch et al. (2014) for Córdoba-CABA monitoring site (see their Fig. 11).

The elevated concentrations observed on 16 October can indeed be identified as ash, since the independent METAR/SPECI reports indicate the presence of ash at the Aeroparque airport located only $1 \mathrm{~km}$ away from the research site (see Sect. 3.2).

Moreover, Level 2 AERONET measurements from CEILAP-BA indicate a significant contribution of the fine mode to the total AOD on 15 October (FMF varies from 0.48 to 0.89 , with a mean value of 0.69 ), whereas during the following days the AOD data indicate that the coarse mode dominates (FMF ranged from 0.29 to 0.32 with a mean value of 0.30 on 16 October and between 0.37 and 0.47 with a mean of 0.40 on 17 October). On 16 October few AOD level 2 data (from 07:00 to 08:00 LST) are available due to the presence of clouds, ash and dust over the site. These results are in accordance with those reported by Papayannis et al. (2012) over Europe after the Eyjafjallajökull eruption.

Figure $5 \mathrm{c}$ indicates that on 15 October the values of the Ångström exponent and $\mathrm{AOD}_{500 \mathrm{~nm}}$ are typical of anthropogenic (mostly urban) sources, coinciding with the greater proportion of fine aerosols. Contrarily, from 16 to 17 October the small Ångström exponents are related to coarse-mode aerosols in agreement with the fine-mode fraction behavior. The elevated $\mathrm{AOD}_{500 \mathrm{~nm}}$ coincides with the presence of the resuspended ash plus dust on the atmospheric column over Buenos Aires. It is notable how both parameters fall outside their mean values and standard deviations, particularly on 16 October. These results show behavior similar to that reported by Eck et al. (2005, 2010), Kim et al. (2011), Papayannis et al. (2012) and Lyamani et al. (2015).

\subsection{Satellite measurements}

Figure 6 shows the CALIOP browser images corresponding to the total attenuated backscatter (TAB) at $532 \mathrm{~nm}$ and the aerosol subtype for the times of the overpass of the satellite over the region of the present study. The TAB signal strength is provided by the CALIPSO team in a color code such that cirrus clouds appear in gray/red/yellow colors and mid- and low-altitude clouds in white/gray/red colors. Aerosols show up as green/yellow/orange/red colored features.

Based on analyses of the CALIOP data aiming to discriminate clouds from aerosols, Liu et al. (2009) found that clouds have a bimodal distribution centered, respectively, at $\sim 0.1$ and $\sim 0.01 \mathrm{~km}^{-1} \mathrm{sr}^{-1}$ of attenuated backscatter and $\sim 0.95$ and $\sim 1$ of color ratio, while aerosols have a single-mode distribution centered at $\sim 0.003 \mathrm{~km}^{-1} \mathrm{sr}^{-1}$ of attenuated backscatter and $\sim 0.45$ of color ratio. There is a small overlap region mainly seen between 0.004 and $0.01 \mathrm{~km}^{-1} \mathrm{sr}^{-1}$ for TAB and $0.5-0.9$ for the color ratio. Dust aerosols usually have large backscatter color ratios due to their large size (Seinfeld and Pandis, 2006). The magnitudes of depolarization ratios for cirrus and dense water clouds are, respectively, around $0.5-0.6$ and 1 . These values are larger than those for aerosols (from $\sim 0$ to 0.1 ). Dust particles normally have larger depolarization ratios due to their asphericity $(\sim 0.2-0.4)$. In their aerosol subtyping algorithm, Omar et al. (2009) found that although the distributions of total attenuated color ratios are not identical, the mean values for the types dust, smoke and polluted dust are centered around 0.5 .

Focusing on the detection of volcanic ash, Winker et al. (2012) found the magnitude of the attenuated backscatter of the ash layer to vary from $3.5 \times 10^{-3}$ to $5 \times 10^{-3} \mathrm{~km}^{-1} \mathrm{sr}^{-1}$, the magnitude of the volume depolarization from around 0.3 to 0.4 and the magnitude of the attenuated color ratio between 0.5 and 0.7 . Vernier et al. (2013) showed that the PCCVC plume was primarily made of highly depolarized ash. The volcanic ash layers exhibited color ratios near 0.5 , significantly lower than unity, as is observed in ice clouds and a high volume depolarization ratio (0.3-0.4).

On 14 October, the CALIPSO profiles revealed a zone with TAB ranging from $2.5 \times 10^{-3}$ to $4 \times 10^{-3} \mathrm{~km}^{-1} \mathrm{sr}^{-1}$ located over the Patagonian Steppe $\left(\sim 39^{\circ} \mathrm{S}\right.$ and $65^{\circ} \mathrm{W}$, reaching $2 \mathrm{~km}$ height) (Fig. 6a). The vertical feature mask (not shown) clearly discriminates this feature as aerosol and the aerosol subtype is dust (Fig. 6b). This zone displayed volume depolarization ratios between 0.3 and 0.4 and color ratios near 0.5 (not shown). This behavior is in agreement with the findings of Winker et al. (2012) and Vernier et al. (2013) for volcanic ash.

The CALIOP observations during the nighttime satellite pass on 15 October depict $\mathrm{TAB}$ values ranging between $7 \times 10^{-4}$ and $3 \times 10^{-2} \mathrm{~km}^{-1} \mathrm{sr}^{-1}$ at $\sim 40^{\circ} \mathrm{S}, 64.5^{\circ} \mathrm{W}$ to $34^{\circ} \mathrm{S}, 63^{\circ} \mathrm{W}$, rising up to $3 \mathrm{~km}$ above ground (Fig. 6c). The depolarization ratios (not shown) range from 0.1 to 0.5 , where the predominant values are between 0.3 and 0.4 with a heterogeneous structure. The attenuated color ratio (not shown) exhibits a majority of values around $0.5-0.6$, but they also show magnitudes around 1 , consistent with the presence 

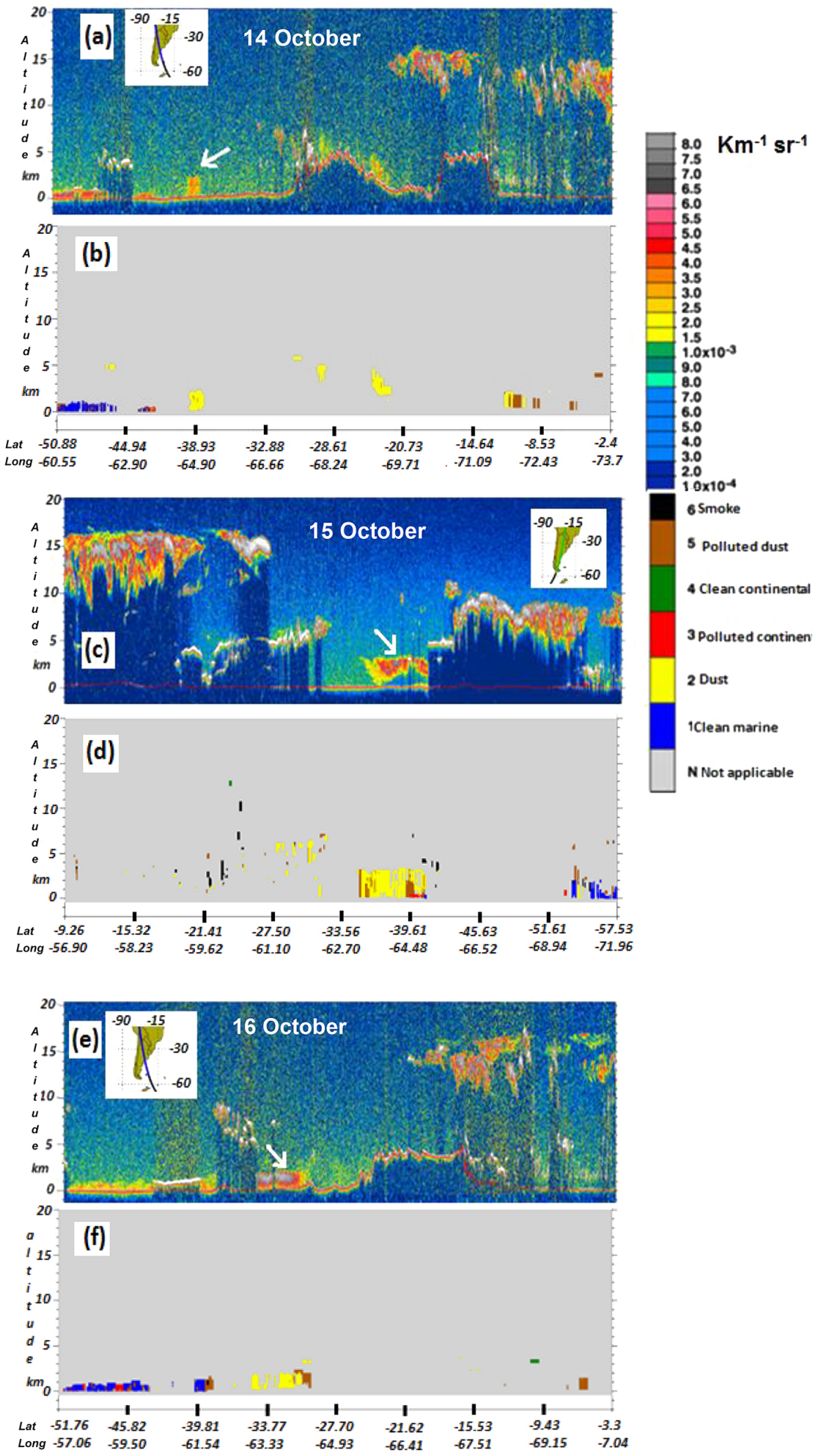

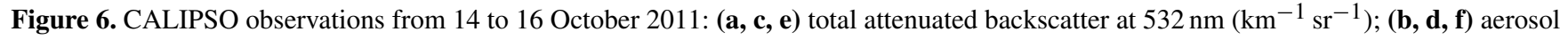
subtype. The ground track is included in the insert.

of mixed clouds (water/ice) at southern latitudes, coinciding with the vertical feature mask (VFM) (not shown). Figure 6d shows that these features decoded by the CALIPSO aerosol inversion algorithms correspond to mostly dust, polluted dust and polluted continental. 
For the daytime CALIPSO pass of 16 October, the lidar reported $532 \mathrm{~nm}$ total attenuated backscatter ranging from $1.5 \times 10^{-3}$ to $2 \times 10^{-2} \mathrm{~km}^{-1} \mathrm{sr}^{-1}$, located at $\sim 34^{\circ} \mathrm{S}, 63^{\circ} \mathrm{W}$ to $29^{\circ} \mathrm{S}, 64.5^{\circ} \mathrm{W}$, with a vertical extent reaching $2500 \mathrm{~m}$ (Fig. 6e). The gray colors are associated with clouds. The depolarization ratio is dominated by values around $0.4-0.5$ (not shown) and the attenuated color ratio (not shown) in the upper part of the signature mostly corresponds to water (1). Below this layer a mixture of values from 0.5 to 0.7 is observed in coincidence with water and unknown values (the VFM (not shown) has low confidence in discriminating the features/aerosols). The aerosol layer is identified as dust and polluted dust as shown in Fig. $6 \mathrm{f}$.

\section{Analysis of HYSPLIT simulations}

\subsection{Methodology and setup}

Four months after the initial eruption of the PCCVC in June, the activity of the volcanic complex was weak and the ash column relatively shallow during the period studied here; hence there was little chance of fresh emissions reaching Buenos Aires in October. The observed ash plume and the ash deposited on the runways and surrounding area of the city airport on 16 October have to be associated with a resuspension event of previously deposited volcanic ash in northern Patagonia. The synoptic analysis and the thermodynamic soundings of the days prior to the arrival of the ash plume in Buenos Aires are all consistent with the hypothesis of advection after an event of ash resuspension. In order to test this hypothesis we use the HYSPLIT model (available from http://www.arl.noaa.gov/ready/hysplit4.html) with the "dust storm" module.

Events of resuspension of volcanic ash are dynamically similar to dust storms, so the lifting and subsequent advection of the ash particles can be simulated using the dust emission algorithm included in the current public version of HYSPLIT, which has been previously evaluated for several windblown dust emissions (Draxler et al., 2001; Stein et al., 2015).

The "dust storm" option of HYSPLIT uses the concept of a threshold friction velocity dependent on surface roughness and soil type. A pre-processor for "desert" soil type identifies a dust emission cell, and particles are emitted when the local wind speed exceeds the threshold set for the particular soil characteristics (Draxler et al., 2001, 2013). The numerical experiments simulating the dust storm were performed utilizing the Kantha-Clayson turbulence parameterization in the vertical and horizontal turbulence proportional to the vertical. A total of 45000 particles were resuspended at each grid cell where the desert soil type is found and when the threshold wind velocity is exceeded. The number of particles was chosen according to those reported in the literature (Escudero et al., 2006; Dupart et al., 2012).
Leadbetter et al. (2012) stressed that incorporating soil moisture and soil-type changes such as those that occur in the case of ash deposits is crucial for the modeling of resuspension. In order to better represent the soil conditions during this event, we modified the default land-use file (that has a similar resolution as the GDAS meteorological fields) with the inclusion of desert soil grid points in the location of the deposited ash in the Patagonian Steppe.

Runs were initialized on 13 October 2011 at 18:00 UTC and lasted for $96 \mathrm{~h}$. We present here only a few selected times from the simulations that coincide with the overpass of the CALIPSO satellite in order to perform a qualitative analysis of the results. In particular, we show the results for $14 \mathrm{Oc}-$ tober at 18:00 UTC (Fig. 7a-c), 15 October at 06:00 UTC (Fig. 7d-f) and 16 October at 18:00 UTC (Fig. 7g-i).

\subsection{Analysis of modeling results}

The HYSPLIT dust algorithm clearly located the emission cells at the arid zone over the Patagonian Steppe and as this zone was coincident with the CALIPSO overpass, we also use the resulting vertical cross sections. On 14 October at 18:00 UTC, the simulated horizontal plume (Fig. 7a) is consistent with the synoptic environment and the advection of the particles is carried out by strong near-surface SW winds veering clockwise (cyclonic circulation for the Southern Hemisphere) and reaching the Atlantic Ocean. The simulated vertical cross sections around the time of the satellite overpass highly resemble the lidar measurements in horizontal location $\left(\sim 40^{\circ} \mathrm{S}, 64^{\circ} \mathrm{W}\right)$ and also in the height of the plume near $2 \mathrm{~km}$ (compare Figs. 7b, c with 6a, b).

Although the CALIPSO ground track is tangential to the area of interest and the zone of particle emissions, a comparative analysis with the modeling results for 15 October at 06:00 UTC is still instructive. The horizontal plume pattern (Fig. 7d) resembles the low-level flow as described in Sect. 3.2 and shown in Fig. 3a (although the depicted meteorological field is $6 \mathrm{~h}$ later, the field configuration is quite similar). The distinguishable feature measured by CALIPSO, which contains cloud plus volcanic ash plus dust located around $38^{\circ} \mathrm{S}, 64^{\circ} \mathrm{W}$, previously analyzed (see Fig. 6c, d), is captured by the model although the vertical extent is underestimated (Fig. 7e, f).

On 16 October at 18:00 UTC, the HYSPLIT particle plume displacement follows the strong SW winds over the southern Buenos Aires province. The divergent feature of the plume (Fig. 7g) over the Atlantic Ocean is fairly consistent with the meteorological fields (see Fig. 3c, d). The location of the CALIPSO trajectory (west of the HYSPLIT particle plume) precludes the comparison with the vertical cross sections.

The model reproduces the dust plume being advected from the steppe into the Buenos Aires Metropolitan Area and the highly populated cities of Córdoba $\left(31.42^{\circ} \mathrm{S}, 64.18^{\circ} \mathrm{W}\right.$; $448 \mathrm{~m}$ a.s.l.), Rosario $\left(32.95^{\circ} \mathrm{S}, 60.65^{\circ} \mathrm{W} ; 25 \mathrm{~m}\right.$ a.s.l.) and 

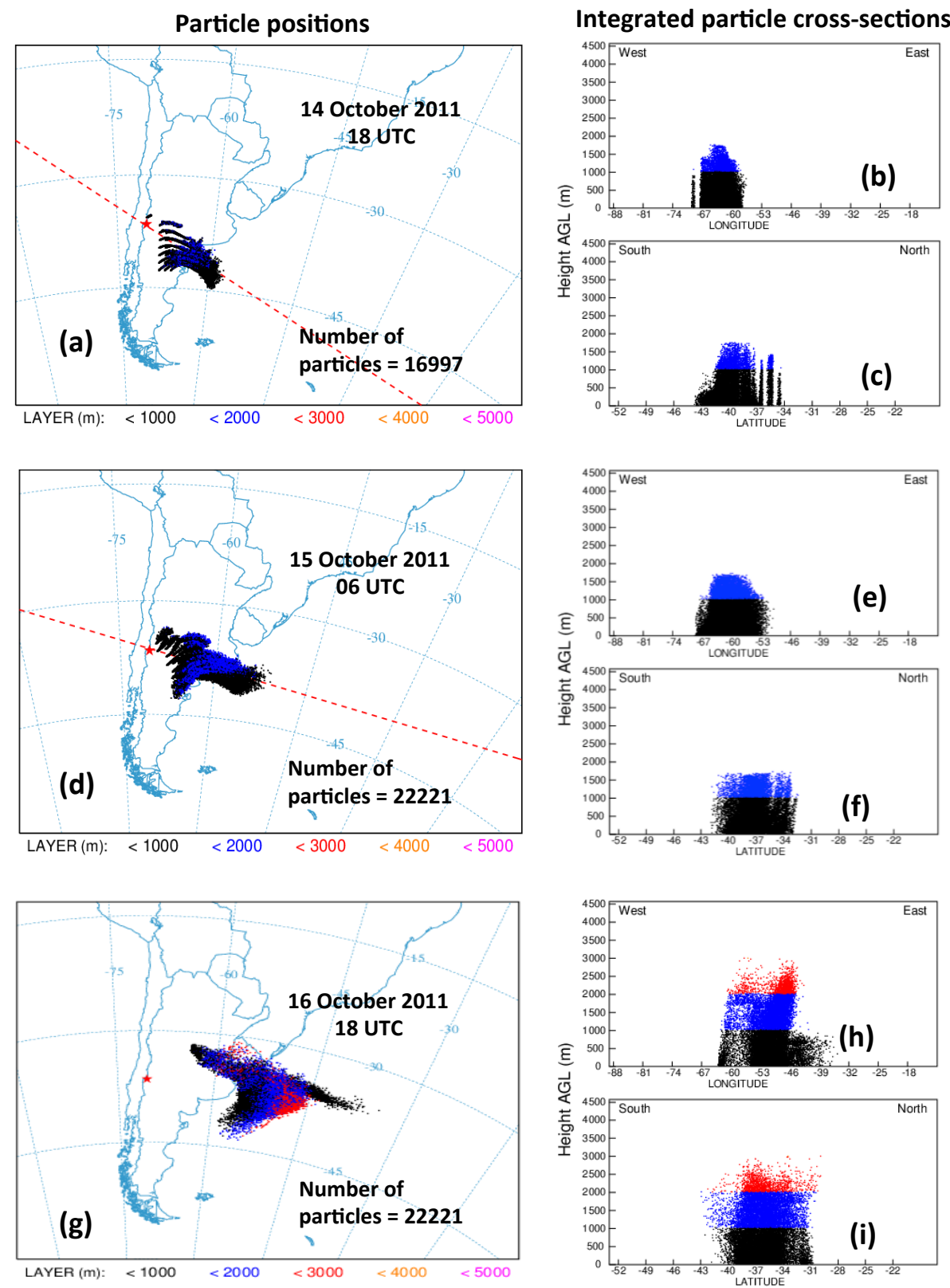

Figure 7. HYSPLIT simulations from 14 to 16 October 2011: (a, d, g) particle positions at surface; (b, e, h) W-E integrated particle cross sections; (c, f, i) S-N integrated particle cross sections. The red dashed line denotes the regression line through the particle positions.

Santa Fe $\left(31.63^{\circ} \mathrm{S}, 60.68^{\circ} \mathrm{W} ; 25 \mathrm{~m}\right.$ a.s.l.). In addition to the evidence from the CALIOP measurements, the METAR information reported volcanic ash at those locations, as well. Córdoba reported volcanic ash from 23:00 UTC on 16 October until 13:00 UTC on 18 October and Rosario from 17:00 UTC on 16 October to 13:00 UTC on 17 October, consistent with the northward displacement of the plume.

Although the goal of our study is not the comparison of the HYSPLIT dust storm module results with other model simulations, a brief qualitative comparison with results reported by Folch et al. (2014) for 16 October 18:00 UTC is done. We compared the horizontal distribution of particles as well as the time of arrival of the ash plus dust over the airports where we have information (METAR/SPECI). The Folch et al. (2014) study was focused on the calibration and evaluation of their new resuspension module within a refined numerical modeling system WRF-ARW/FALL3D specially designed for volcanic eruptions and dispersion of volcanicorigin material. The FALL3D model can predict the field of volcanic material concentrations. They evaluated the performance of different resuspension modules with derived quantities (total suspended particles derived from visibility data 
which is reported by the SMN weather stations) using as control case the measured $\mathrm{PM}_{10}$ concentrations in Buenos Aires city. Analyzing their fields of mass concentration (see their Fig. 7) and comparing with our HYSPLIT simulation at similar times, and keeping in mind that our fields are "horizontal particle distributions", a similar behavior of the horizontal distribution is evident and the better agreement is with their new Shao $(\mathrm{SH})$ scheme.

As previously mentioned, Folch et al. (2014) calibrated the resuspension in the FALL3D model analyzing the performance of three parameterizations originally developed for dust particle resuspension. In their calibration, they used visibility reports in Aeroparque (see their Fig. 6) and afterwards they made a comparison with the remaining proxy data (estimated concentrations from 15 meteorological stations and plume arrival times (see their Figs. 8 and 9). They found an underestimation of concentrations in the far field stations with all resuspension schemes. Afterwards, they compared the characteristic arrival time in terms of the decrease of the concentration to half the maximum value, with similar results for the three schemes. Focusing on the $\mathrm{PM}_{10}$ concentrations in the same event that we are analyzing in our paper, Folch et al. (2014) mention that the schemes that rely on the emission strength and friction velocity (the more sophisticated ones, Marticorena and Bergametti (MB) scheme, and $\mathrm{SH}$ ) widely underestimate the measured concentrations at GCBA monitoring stations. They concluded that these results are due to the underestimation of the friction velocity by the meteorological model (WRF-ARW) that provides the input meteorological field to FALL3D. In fact they show that the $\mathrm{MB}$ and $\mathrm{SH}$ schemes need the friction velocity provided by the meteorological model, which in turn is strongly dependent on the soil moisture field in the same meteorological model. They found best agreement when their predicted concentrations considering dry soil were compared to $\mathrm{PM}_{10}$ GCBA measurements (see their Fig. 11). As a consequence, our results are consistent with their findings in spite of the more simple modeling strategy we have applied. As we mention in the introduction, the driving mechanisms of the dust storm module in HYSPLIT are the near-surface wind speed and the soil type. The deposited ash was already in an arid region (the Patagonian Steppe) which is frequently a source of windblown dust. In addition, in this particular event, the soil conditions were drier than the climatological values as documented in the SMN reports.

\section{Summary and conclusions}

In June 2011, the PCCVC in southern Chile erupted explosively and released an ash plume that caused air traffic disruption throughout the Southern Hemisphere. The eruptive activity decreased in intensity by July and low-level isolated emission events lasted until February 2012. A significant amount of PCCVC ejecta of the initial eruption were deposited on the ground in neighboring Argentina. Some of that material was later resuspended by low-level winds, similar to particles in a dust storm, and transported around 1400$1700 \mathrm{~km}$ from the emission source. One such resuspension episode that occurred in mid-October 2011 impacted Buenos Aires and resulted in the closure of both its airports.

In this study we analyze the meteorological conditions that led to the episode of volcanic ash resuspension and its transport to the city of Buenos Aires and relate the event with the measurements of aerosol properties being carried out at CU.

The synoptic conditions supported the presence of very intense near-surface winds in northern Patagonia, where the ash had been deposited after the initial eruptions of the PCCVC. Moreover, the patterns were optimal for the transport to the region of Buenos Aires. The analysis of thermodynamic soundings indicated that the presence of the resuspended ash resulted in a drying of the lower troposphere, an effect already reported in studies elsewhere as a result of the ash composition.

Light-absorbing particles, not associated with typical urban pollution in Buenos Aires, were identified on 16 October, coinciding with METAR reports of ash on the runways at both airports and very large $\mathrm{PM}_{10}$ concentrations reported by the air quality network in the city, exceeding the daily standard by up to $60 \%$. Moreover, the ceilometer measurements detected the presence of the ash plume, with a nonuniform vertical structure that clearly impacted the $\mathrm{CU}$ research site from midnight on 15 October until late evening on 16 October. Independent measurements from AERONET indicated an increase in the aerosol load, and spectral features of the aerosol particles consistent with the presence of the resuspended ash plus dust advected towards the city. In consequence, the information provided by these measurements is further evidence that in this event the airborne aerosols in Buenos Aires city are in the coarse-mode fraction and not typical urban pollution that is in the fine-mode fraction. On the regional scale, the lidar measurements from the CALIOP satellite supported the analysis of the resuspension and further transport of the ash plus dust. The HYSPLIT model with the dust storm module was used to simulate the episode based on the similarity of the dynamics of ash resuspension and dust storms with satisfactory results.

The resuspension of aged volcanic ash combined with dust from the Patagonian Steppe appears to be a result of a superposition of several factors:

- The region where ash was deposited is a recognized source of windblown dust due to the combination of the arid soil and quasi-permanent strong westerly winds, conditions that favor lifting mechanisms for dust.

- The climatological analysis revealed 2011 as a particularly dry year. 
- The meteorological conditions on these days were characterized by intense southwesterly winds ahead of a high-pressure system over the Patagonian Steppe.

In general, the simulations with the HYSPLIT model captured the resuspension episode and the ash plus dust plume timing and location after the surface soil type appropriate for the Patagonian Steppe had been incorporated in the model. The introduction of the proper soil type in the model was crucial for producing reasonable results.

This study demonstrates the applicability of the dust storm module in HYSPLIT as an adequate tool for the simulation of ash resuspension under the conditions prevalent in Patagonia. Given the large number of volcanoes in the Patagonian Andes and the prevailing westerly winds, it is very likely that most of the ash from future eruptions will again fall over the Patagonian Steppe, where conditions will be conducive to resuspension episodes that can potentially affect air traffic in the vicinity of large urban centers.

\section{Data availability}

The ceilometer raw data analyzed in this investigation are available by contacting anagulke@gmail.com. AERONET and CALIPSO information is respectively available at http://aeronet.gsfc.nasa.gov/ and http://www-calipso.larc.nasa.gov/. The hourly surface meteorological data and upper-air information are available by contacting SMN at smn@smn.gob.ar. The GDAS meteorological data are accessible at https://www.ncdc.noaa.gov/data-access/model-data/ model-datasets/global-data-assimilation-system-gdas, the NOAA's National Centers for Environmental Information. The HYSPLIT model and the meteorological files to drive the simulations are available from http://www.arl.noaa.gov/ready/hysplit4.html. Monthly $\mathrm{PM}_{10}$ records are available from http://www.buenosaires.gob.ar/ agenciaambiental/monitoreoambiental, while hourly $\mathrm{PM}_{10}$ data are accessible by contacting the air quality division of the city government at http://www.buenosaires.gob.ar/ agenciaambiental/maildecontacto.

\section{The Supplement related to this article is available online at doi:10.5194/nhess-16-2159-2016-supplement.}

Acknowledgements. This research was partially funded by projects UBACyT X224, 20020100101013 and 20020130100771 , ANPCyT PICT 08-1739 in Argentina and AO-LEFE-CHAT 875064 from CNRS, France. Universidad Nacional Autónoma de México (UNAM) is gratefully acknowledged for covering the costs of transportation of the equipment from Mexico City to Buenos Aires. Partial funding was also provided by grant Conacyt-Semarnat
23498 in Mexico. The National Weather Service of Argentina provided the upper-air soundings and surface meteorological observations. The authors would like to thank B. Holben and the AERONET PIs for collecting the aerosol observations around the world. NCEP is acknowledged for the meteorological data. NASA is acknowledged for the CALIPSO and MODIS images and NOAA for HYSPLIT model. The Air Quality Monitoring Network of the city of Buenos Aires is acknowledged for the $\mathrm{PM}_{10}$ measurements. We also thank María Inés de Casas from GCBA for providing hourly $\mathrm{PM}_{10}$ data. SERNAGEOMIN from Chile is gratefully acknowledged for providing the daily reports that describe the eruptive process. Finally, the authors are grateful to the staff of the Facultad de Ciencias Exactas y Naturales (UBA) for their invaluable help and logistic support during the campaign.

Edited by: U. Ulbrich

Reviewed by: two anonymous referees

\section{References}

Bonadonna, C., Cioni, R., Pistolesi, M., Elissondo, M., and Baumann, V.: Sedimentation of long-lasting wind-affected volcanic plumes: The example of the 2011 rhyolitic Cordón Caulle eruption, Chile, B. Volcanol., 77, 1-19, doi:10.1007/s00445-0150900-8, 2015a.

Bonadonna, C., Pistolesi, M., Cioni, R., Degruyter, W., Elissondo, M., and Baumann V.: Dynamics of wind-affected volcanic plumes: The example of the 2011 Cordón Caulle eruption, Chile, J. Geophys. Res. Earth, 120, 2244-2261, doi:10.1002/2014JB011478, 2015b.

Casadevall, T. J.: Volcanic Hazards and Aviation Safety: Lessons of the Past Decade, Flight Safety Foundation - Flight Safety Digest, 1-9, available at: http://flightsafety.org/archives-and-resources/ publications/flight-safety-digest/flight-safety-digest-1993 (last access: 20 December 2015), 1993.

Casadevall, T. J.: The 1989-1990 eruption of Redoubt Volcano, Alaska: impacts on aircraft operations, J. Volcanol. Geoth. Res., 62, 301-316, doi:10.1016/0377-0273(94)90038-8, 1994.

Collini, E., Osores, S., Folch, A., Viramonte, J. G., Villarosa, G., and Salmuni, G.: Volcanic ash forecast during the June 2011 Cordón Caulle eruption, Nat. Hazards, 66, 389-412, doi:10.1007/s11069-012-0492-y, 2013.

Draxler, R. R. and Hess, G. D.: An overview of the HYSPLIT4 modelling system for trajectories, dispersion, and deposition, Aust. Meteorol. Mag., 47, 295-308, 1998.

Draxler, R. R., Gillette, D. A., Kirkpatrick, J. S., and Heller, J.: Estimating $\mathrm{PM}_{10}$ Air Concentrations from Dust Storms in Iraq, Kuwait, and Saudi Arabia, Atmos. Environ., 35, 4315-4330, doi:10.1016/S1352-2310(01)00159-5, 2001.

Draxler, R. R., Stunder B., Rolph, G. Stein, A., and Taylor, A.: HYSPLIT4 Users Guide, NOAA Air Resources Laboratory, Silver Spring, MD, USA, 212 pp., available at: http://ready.arl.noaa. gov/HYSPLIT.php (last access: 20 December 2015), 2013.

Dubovik, O., Holben, B., Eck, T. F., Smirnov, A., Kaufman, Y. J., King, M. D., Tanre, D., and Slutsker, I.: Variability of absorption and optical properties of key aerosol types observed in worldwide locations, J. Atmos. Sci., 59, 590-608, doi:10.1175/15200469(2002)059<0590:VOAAOP>2.0.CO;2, 2002. 
Dupart, Y., King, S. M., Nekat, B., Nowak, A., Wiedensohler, A., Herrmann, H., David, G., Thomas, B., Miffre, A., Rairoux, P., D’Anna, B., and George, C.: Mineral dust photochemistry induces nucleation events in the presence of $\mathrm{SO}_{2}$, P. Natl. Acad. Sci. USA, 109, 20842-20847, doi:10.1073/pnas.1212297109, 2012.

Eck, T. F., Holben, B. N., Reid, J. S., Dubovik, O., Smirnov, A., O’Neill, N. T., Slutsker, I., and Kinne, S.: Wavelength dependence of the optical depth of biomass burning, urban, and desert dust aerosols, J. Geophys. Res., 104, 31333-31349, doi:10.1029/1999jd900923, 1999.

Eck, T. F., Holben, B. N., Dubovik, O., Smirnov, A., Goloub, P., Chen, H. B., Chatenet, B., Gomes, L., Zhang, X. Y., Tsay, S. C., Ji, Q., Giles, D., and Slutsker, I.: Columnar aerosol optical properties at AERONET sites in Central Eastern Asia and aerosol transport to the Tropical Mid-Pacific, J. Geophys. Res., 110, D06202, doi:10.1029/2004JD005274, 2005.

Eck, T. F., Holben, B. N., Sinyuk, A., Pinker, R. T., Goloub, P., Chen, H., Chatenet, B., Li, Z., Singh, R. P., Tripathi S. N., Reid, J. S., Giles, D. M, Dubovik, O., O'Neill, N. T., Smirnov, A., Wang, P., and Xia, X.: Climatological aspects of the optical properties of fine/coarse mode aerosol mixtures, J. Geophys. Res., 115, D19205, doi:10.1029/2010JD014002, 2010.

Ellrod, G. P., Connell, B., and Hillger, D.: Improved detection of airborne volcanic ash using multispectral infrared satellite data, J. Geophys. Res., 108, 4356, doi:10.1029/2002JD002802, 2003.

Escudero, M., Stein, A., Draxler, R. R., Querol, X., Alastuey, A., Castillo, S., and Avila, A.: Determination of the contribution of northern Africa dust source areas to $\mathrm{PM}_{10}$ concentrations over the central Iberian Peninsula using the Hybrid Single-Particle Lagrangian Integrated Trajectory model (HYSPLIT) model, J. Geophys. Res., 111, D06210, doi:10.1029/2005JD006395, 2006.

Fabricante, I., Oesterheld, M., and Paruelo, J. M.: Annual and seasonal variation of NDVI explained by current and previous precipitation across Northern Patagonia, J. Arid Environ., 73, 745753, doi:10.1016/j.jaridenv.2009.02.006, 2009.

Folch, A., Mingari, L., Osores, M. S., and Collini, E.: Modeling volcanic ash resuspension - application to the 14-18 October 2011 outbreak episode in Central Patagonia, Argentina, Nat. Hazards Earth Syst. Sci., 14, 119-133, doi:10.5194/nhess-14-119-2014, 2014.

Freudenthaler, V.: Depolarization ratio profiling at several wavelengths in pure Saharan dust using SAMUM 2006, Tellus B, 61, 165-179, doi:10.1111/j.1600-0889.2008.00396.x, 2006.

Gaitán, J. J., Ayesa, J. A., Umaña, F., Raffo, F., and Bran, D. B.: Cartography of affected area by volcanic ashes at Rio Negro and Neuquen Provinces, INTA Technical Report, $8 \mathrm{pp}$., available at http://inta.gob.ar/sites/default/files/ script-tmp-cartografa_cenizas.pdf, (last access: 7 November 2015), 2011.

GCBA: Monthly Report: available at http://www.buenosaires. gob.ar/sites/gcaba/files/pm10_laboca_octubre_2011.pdf, (last access: 13 October 2015), 6 pp., 2016).

Gillette, D. and Passi, R.: Modeling dust emission caused by wind erosion, J. Geophys. Res., 93, 14233-14242, doi:10.1029/JD093iD11p14233, 1988.

$\mathrm{Gu}$, Y., Rose, W. I., and Bluth, G. S.: Retrieval of mass and sizes of particles in sandstorms using two MODIS IR bands: A case study of April 7, 2001 sandstorm in China, Geophys. Res. Lett., 30, 1805, doi:10.1029/2003GL017405, 2003.

Hadley, D. and Hufford, G. L.: Resuspension of relic volcanic ash and dust from Katmai: still an aviation hazard, Weather Forecast., 19, 829-840, doi:10.1175/15200434(2004)019<0829:RORVAA>2.0.CO;2, 2004.

Holben, B. N., Eck, T. F., Slutsker, I., Tanré, D., Buis, J. P., Setzer, A., Vermote, E., Reagan, J. A., Kaufman, Y., Nakajima, T., Lavenu, F., Jankowiak, I., and Smirnov, A.: AERONET - A federated instrument network and data archive for aerosol characterization, Remote Sens. Environ., 66, 1-16, doi:10.1016/S00344257(98)00031-5, 1998.

Hu, Y., Winker D., Vaughan M., Lin B., Omar, A., Trepte, C., Flittner, D. Yang, P., Nasiri, S. L., Baum, B., Sun, W., Liu, Z., Wang, Z., Young, S., Stamnes, K. Huang, J. Kuehn, R., and Holz, R.: CALIPSO/CALIOP Cloud Phase Discrimination Algorithm, J. Atmos. Ocean. Tech., 26, 2293-2309, doi:10.1175/2009JTECHA1280.1, 2009.

Jones, A. R., Thomson, D. J., Hort, M., and Devenish, B.: The U.K. Met Office's next-generation atmospheric dispersion model, NAME III, in Air Pollution Modeling and Its Application XVII (Proceedings of the 27th NATO/CCMS International Technical Meeting on Air Pollution Modelling and its Application), edited by: Borrego, C. and Norman, A. L., Springer, New York, 580589, 2007.

Jugder, D., Shinoda, M., Sugimoto, N., Matsui, I., Nishikawa, M., Park, S.-U., Chun, Y.-S., and Park, M.-S.: Spatial and temporal variations of dust concentrations in the Gobi Desert of Mongolia, Global Planet. Change, 78, 14-22, doi:10.1016/j.gloplacha.2011.05.003, 2011.

Kim, D., Chin, M., Yu, H., Eck, T. F., Sinyuk, A., Smirnov, A., and Holben, B. N.: Dust optical properties over North Africa and Arabian Peninsula derived from the AERONET dataset, Atmos. Chem. Phys., 11, 10733-10741, doi:10.5194/acp-1110733-2011, 2011.

Lathem, T. L., Kumar, P., Nenes, A., Dufek, J., Sokolik, I. N., Trail, M., and Russell, A.: Hygroscopic properties of volcanic ash, Geophys. Res. Lett., 38, L11802, doi:10.1029/2011GL047298, 2011.

Leadbetter, S. J., Hort, M. C., Von Lowis, S., Weber, K., and Witham, C. S.: Modeling the resuspension of ash deposited during the eruption of Eyjafjallajökull in 2010, J. Geophys. Res., 117, D00U10, doi:10.1029/2011JD016802, 2012.

Liu, Z., Vaughan, M., Winker, D., Kittaka, C., Getzewich, B., Kuehn, R., Omar, A., Powell, K., Trepte, C., and Hostetler, C.: The CALIPSO lidar cloud and aerosol discrimination: version 2 algorithm and initial assessment of performance, J. Atmos. Ocean. Tech., 26, 1198-1213, doi:10.1175/2009JTECHA1229.1, 2009.

Lyamani, H., Valenzuela, A., Perez-Ramirez, D., Toledano, C., Granados-Muñoz, M. J., Olmo, F. J., and Alados-Arboledas, L.: Aerosol properties over the western Mediterranean basin: temporal and spatial variability. Atmos. Chem. Phys., 15, 2473-2486, doi:10.5194/acp-15-2473-2015, 2015.

Miffre, A., David, G., Thomas, B., Abou Chacra, M., and Rairoux, P.: Interpretation of accurate UV polarization lidar measurements: application to volcanic ash number concentration retrieval, J. Atmos. Ocean. Tech., 29, 558-568, doi:10.1175/JTECH-D-11-00124.1, 2012. 
Omar, A. H., Winker, D. M., Kittaka, C., Vaughan, M. A., Liu, Z., Hu, Y., Trepte, C. R., Rogers, R. R., Ferrare, R. A., Lee, K., Kuehn, R. E., and Hostetler, C. A.: The CALIPSO automated aerosol classification and lidar ratio selection algorithm, J. Atmos. Ocean. Tech., 26, 1994-2014, doi:10.1175/2009JTECHA1231.1, 2009.

O’Neill, N. T., Dubovik, O., and Eck, T. F.: Modified Ångström coefficient for the characterization of sub-micron aerosols, App. Opt., 40, 15, 2368-2374, 2001a.

O’Neill, N. T., Eck, T. F., Holben, B. N., Smirnov, A., Dubovik, O., and Roger, A.: Bimodal size distribution influences on the variation of Ångström derivatives in spectral and optical depth space, J. Geophys. Res., 106, 9787-9806, doi:10.1029/2000JD900245, 2001b.

O’Neill, N. T., Eck, T. F., Smirnov, A., Holben, B. N., and Thulasiraman, S.: Spectral discrimination of coarse and fine mode optical depth, J. Geophys. Res., 108, 4559-4573, doi:10.1029/2002JD002975, 2003.

O’Neill, N. T., Eck, T. F., Smirnov, A., Holben, B., and Thulasiraman, S.: Spectral Deconvolution algorithm Technical memo, revised 26 April 2006, 15 pp., available at: http://aeronet.gsfc.nasa. gov/new_web/system_descriptions.html (last access: 11 April 2016), 2006.

Papayannis, A., Mamouri, R. E., Amiridis, V., Giannakaki, E., Veselovskii, I., Kokkalis, P., Tsaknakis, G., Balis, D., Kristiansen, N. I., Stohl, A., Korenskiy, M., Allakhverdiev, K., Huseyinoglu, M. F., and Baykara, T.: Optical properties and vertical extension of aged ash layers over the Eastern Mediterranean as observed by Raman lidars during the Eyjafjallajökull eruption in May 2010, Atmos. Environ., 48, 56-65, doi:10.1016/j.atmosenv.2011.08.037, 2012.

Pistolesi, M., Cioni, R., Bonadonna, C., Elissondo, M., Baumann, V., Bertagnini, A., Chiari, L., Gonzales, R., Rossi, M., and Francalanci, L.: Complex dynamics of small-moderate volcanic events: the example of the 2011 rhyolitic Cordón Caulle eruption, Chile, B. Volcanol., 77, 1-24, 2015.

Powell, K., Vaughan, M., Winker, D., Lee, K.-P., Pitts, M., Trepte, C., Detweiler, P., Hunt, W., Lambeth, J., Lucker, P., Murray, T., Hagolle, O., Lifermann, A., Faivre, M., Garnier, A., and Pelon, J.: Cloud - Aerosol LIDAR Infrared Pathfinder Satellite Observations (CALIPSO) Data Management System Data Products Catalog Document No: PC-SCI-503 Release 3.6, 122 pp., 2013.

Prata, A. J.: Infrared Radiative transfer calculations for volcanic ash clouds, Geophys. Res. Lett., 16, 1293-1296, 1989.

Pujol, G. C., Toyos, G., Rabolli, M., and Kalemkarian, M.: Space-borne Products for Operational Volcanic Ash Cloud Monitoring in Argentina, presented at 2nd IUGG-WMO workshop on: ASH DISPERSAL FORECAST AND CIVIL AVIATION, 18-20 November 2013, Geneva, Switzerland, available at: http://www.unige.ch/sciences/terre/mineral/CERG/ Workshop2/Program/P-07_Pujol.pdf, (last access: 19 May 2016), 2013.
Raga, G. B., Baumgardner, D., Ulke, A. G., Torres Brizuela, M. M., and Kucienska, B.: The environmental impact of the PuyehueCordon Caulle 2011 volcanic eruption on Buenos Aires, Nat. Hazards Earth Syst. Sci., 13, 2319-2330, doi:10.5194/nhess-132319-2013, 2013.

Schumann, U., Weinzierl, B., Reitebuch, O., Schlager, H., Minikin, A., Forster, C., Baumann, R., Sailer, T., Graf, K., Mannstein, H., Voigt, C., Rahm, S., Simmet, R., Scheibe, M., Lichtenstern, M., Stock, P., Rüba, H., Schäuble, D., Tafferner, A., Rautenhaus, M., Gerz, T., Ziereis, H., Krautstrunk, M., Mallaun, C., Gayet, J.F., Lieke, K., Kandler, K., Ebert, M., Weinbruch, S., Stohl, A., Gasteiger, J., Groß, S., Freudenthaler, V., Wiegner, M., Ansmann, A., Tesche, M., Olafsson, H., and Sturm, K.: Airborne observations of the Eyjafjalla volcano ash cloud over Europe during air space closure in April and May 2010, Atmos. Chem. Phys., 11, 2245-2279, doi:10.5194/acp-11-2245-2011, 2011.

Seinfeld, J. H. and Pandis, S. N.: Atmospheric Chemistry and Physics: From Air Pollution to Climate Change (2nd ed.), Hoboken, New Jersey, John Wiley \& Sons, Inc., 1232 pp., 2006.

Smirnov, A., Holben, B., Eck, T. F., Dubovik, O., and Slutsker, I.: Cloud-screening and quality control algorithms for the AERONET database, Remote Sens. Environ., 73, 337-349, doi:10.1016/S0034-4257(00)00109-7, 2000.

Stein, A. F., Draxler, R. R., Rolph, G. D., Stunder, B. J. B., Cohen, M. D., and Ngan, F.: NOAA'S HYSPLIT atmospheric transport and dispersion modeling system, B. Am. Meteor. Soc., 96, 20592077, doi:10.1175/bams-d-14-00110.1, 2015.

Ulke, A. G., Torres Brizuela, M. M., Raga, G., and Baumgardner, D.: Microphysical and optical properties of aerosols in Buenos Aires, Ciência e Natura, special issue, 291-294, available at: https://periodicos.ufsm.br/cienciaenatura/article/view/ 9442, 2011.

Vaughan, M. A., Powell, K. A, Kuehn, R. E., Young, S. A., Winker, D. M., Hostetler, C. A., Hunt, W. H., Liu, Z., McGill, M. J., and Getzewich, B. J.: Fully automated detection of cloud and aerosol layers in the CALIPSO lidar measurements, J. Atmos. Ocean. Tech., 26, 2034-2050, doi:10.1175/2009JTECHA1228.1, 2009.

Velasco, I. and Necco, G. V.: Mean values, extremes and standard deviation of aerological data in Argentina, Internal Report, Department of Meteorology, University of Buenos Aires, 275 pp. 1980.

Vernier, J.-P., Fairlie, T. D., Murray, J. J., Tupper, A., Trepte, C., Winker, D., Pelon, J.Garnier, A., Jumelet, J., Pavolonis, M., Omar, A. H., and Powell, K. A.: An advanced system to monitor the 3D structure of diffuse volcanic ash clouds, J Appl Meteorol Clim., 52, 2125-2138, doi:10.1175/JAMC-D-12-0279.1, 2013.

Winker, D. M., Liu, Z., Omar, A., Tackett, J., and Fairlie, D: CALIOP observations of the transport of ash from the Eyjafjallajökull volcano in April 2010, J. Geophys. Res., 117, D00U15, doi:10.1029/2011JD016499, 2012. 